\title{
The INR/USD Exchange Rate Determination: An Empirical Investigation of the Flexible Price Monetary Model in a Vector Auto Regression Framework
}

\author{
Bhargavi Karamcheti1, Vaishali Padake1, T. Geetha² \\ ${ }^{1}$ K. J. Somaiya Institute of Management Studies and Research, Mumbai, India \\ ${ }^{2}$ Jankidevi Bajaj Institute of Management Studies, Mumbai, India \\ Email: jbhargavi203@gmail.com
}

How to cite this paper: Karamcheti, B., Padake, V. and Geetha, T. (2018) The INR/USD Exchange Rate Determination: An Empirical Investigation of the Flexible Price Monetary Model in a Vector Auto Regression Framework. Theoretical Economics Letters, 8, 1070-1082.

https://doi.org/10.4236/tel.2018.85074

Received: March 27, 2018

Accepted: April 16, 2018

Published: April 19, 2018

Copyright $\odot 2018$ by authors and Scientific Research Publishing Inc. This work is licensed under the Creative Commons Attribution International License (CC BY 4.0).

http://creativecommons.org/licenses/by/4.0/

\section{(c) (i) Open Access}

\begin{abstract}
The current study attempts to examine the importance of the Flexible Price Monetary (FPM) Model in explaining the INR/USD exchange rate movement with macro variables such as relative money stock, relative rates of interest and relative output for the period from April 1995 till December 2016. Prior to estimating the empirical model, an array of non-stationarity tests was employed to identify the time series characteristics of the data. Since all the data series were confirmed to be integrated of order one, the multivariate cointegration methodology was used to verify long-run validity of the model. The empirical results garner support for the FPM model in determining INR/USD exchange rate in the long run. The test on direction of causality confirmed existence of causality from FPM variables to exchange rate. The empirical model was estimated in the Vector Auto regression (VAR) framework and variance decomposition analysis was used to examine fluctuation in INR/USD exchange rate caused by the shocks in FPM model variables. It was found that, the monetary model variables explain the exchange rate patterns over a longer period of time but was found not very effective in the short run and hence cannot be considered as a useful framework in explaining the variations in INR/USD exchange rate.
\end{abstract}

\section{Keywords}

Flexible Price Monetary Model, INR/USD, Exchange Rate, VAR, Variance

Decomposition Analysis 


\section{Introduction}

Over the last few decades, the complex behavior of foreign exchange rates and its determination has garnered significant interest both among policy makers and in academia. This trend may be attributed to the growing importance of international trade and the increasing integration of countries with rest of the world. A well-established fact is that fluctuation in exchange rate has serious repercussions on a country's economic activity and trade, impacting the decisions of various stakeholders such as governments, financial institutions and traders alike. Subsequently, considerable research has evolved offering various theoretical models to explain exchange rate behavior and their complex dynamics with various macroeconomic fundamentals.

Surprisingly, most of the empirical literature in the field of international finance is highly biased towards the study of exchange rate behavior of major currencies of advanced economies such as USD, Yen and pound sterling while very little attention has been paid to currencies of emerging economies. Against this backdrop the present article attempts to bridge this gap by investigating the importance of the FPM model in determining the INR/USD exchange rate over a longer time frame. It is pertinent to note here that despite subjecting the monetary approach to empirical investigation to justify its validity across countries; it has been found that there exist great inconsistencies in the findings of such studies across different economies, time horizons and usage of different methodologies thereby making each study distinct by nature.

In the Indian context, the country's foreign exchange rate market is worthy of study as it has transformed itself enormously by bringing about structural changes and overhauling its financial systems post the balance of payments crisis of the early 1990s. The economy has undergone rapid liberalization and has witnessed economic reforms. Reducing exchange rate volatility has become one of the important objectives of the country's central bank especially in the wake rapid globalisation and its passage towards fuller capital account convertibility. The uniqueness of India's exchange rate regime lies in the fact that it has followed a managed floating exchange rate regime which is market driven accompanied by the timely intervention of the Reserve Bank of India (RBI) to bring about orderliness in the forex market. With US figuring in the list of India's prominent trading partners, the current study considers the INR-US dollar exchange rate for our analysis.

In the current study, we aim to examine the dynamic behavior of INR/USD exchange rate mechanism and determine the casual relationship between determinants like money stock, output and interest rate differentials and exchange rate. Secondly, the study aims to empirically verify the predictive ability of the FPM model both in the short and long run under the VAR framework which hypothesizes the presence of a stochastic relationship between the nominal exchange rates and its determinants. The study limits itself to the study of linear models alone and does not include non-linear models. 
The organisation of this paper adheres to the following sequence. Section 2 chronicles India's exchange rate regime from an evolutionary perspective. Section 3 covers the relevant review of literature. The theoretical underpinnings of the study are laid out in Section 4. The data sources and methodology are covered in Section 5. The diagnostic tests conducted in the study and their corresponding results are highlighted in Section 6. Section 7 concludes.

\section{India's Exchange Rate Regime: Evolutionary Perspective}

Over the last four decades, exchange rate regime in India has been subjected to major macroeconomic reforms backed by the opening up of its economy and the liberalisation initiatives taken since the early 1990's. In 1971, the Bretton Woods System marked the end of the fixed exchange rate regime. Subsequently, the INR was pegged with pound sterling. To lessen the risks attached to a single currency peg, from 1975 onwards, the rupee transitioned to a basket peg to ensure exchange rate stability. The late eighties and early nineties witnessed an economic crisis owing to the balance of payments difficulties and the widening balance of payment crisis. In the light of this crisis, India undertook structural reforms. The reforms aimed at strengthening the foreign exchange market besides liberalising exchange control regimes. In 1992, a dual exchange rate system namely, the Liberalised Exchange Rate Management System (LERMS) was introduced to maintain stability and finally to allow the exchange rate to be determined by the market forces. LERMS was replaced with managed floating exchange rate from March 1993. In the recent years India's foreign exchange market has successfully managed to integrate with the money market, government securities market and the capital market while curbing speculative activities and maintaining orderliness in the foreign exchange market [1] (Figure 1).

\section{Literature Review}

Since the early 1970s and 80 s many studies have strongly supported the validity

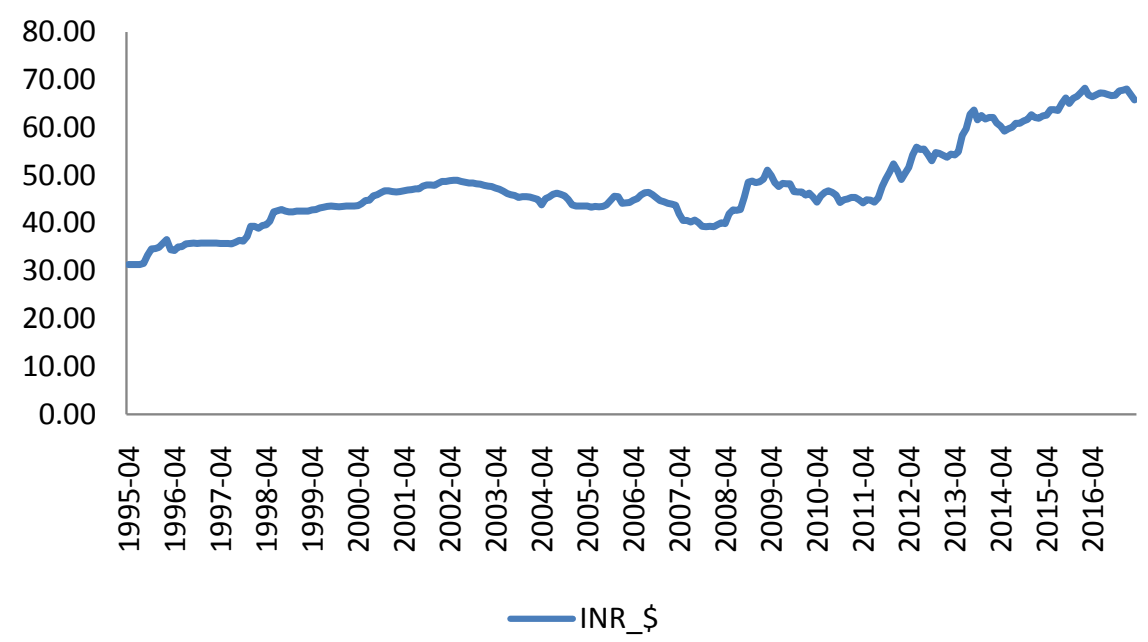

Figure 1. Exchange Rate Movement after adopting Managed Float. Data Source: RBI. 
of the FPM model in modeling rate of exchange. Prominent among the studies are Frenkel [2], Bilson [3], Hodrick [4], Putnam and Woodbury [5], and Dornbusch [6]. Alao et al. [7] examined the relevance of the FPM model in the determination of the Naira-Dollar exchange rate determination spanning a period between 1986 and 2008. The long-run relevance of this model in determining the rate of exchange was confirmed by using the conventional multivariate cointegration procedures. MacDonald and Taylor [8] found similar validity of this model in the context of the USD and British pound. The study validated the performance of the monetary model by adopting the cointegration methodology. Similar empirical evidence was successfully established in the study of Dutt and Ghosh [9] who used monetary fundamentals such as (money stock, interest rates and income) to establish a single unique cointegrating vector between JPY/USD rate of exchange covering an exchange rate regime from 1959 to 1973.The study of Miyakoshi [10] successfully tested the validity of the Korean Won exchange rates in the long run with USD, German Mark and the Japanese Yen for the sample period 1980M1 to 1996M12 using macro variables such as money stock, output and rates of interest. Zhang and Lowinger [11] also employed the cointegration approaches and successfully tested the existence of stochastic linear relationship in the longer period of time between macroeconomic fundamentals such as money stock, real GDP, interest rates in the short run, and expected inflation rate and exchange rates for developed countries like Japan, United Kingdom, Germany and the United States. The study provided mixed results. The results could not garner much support for the FPM model of exchange rate determination for the currency pair having the USD as the base currency, while in the case of other currency pairs like DMark/GBP, JPY/DMark and JPY/GBP the results strongly supported the monetary model of exchange rate.

Extant literature focuses on the performance of the monetary models on the advanced economies. But in the recent past with most of the Asian economies undergoing structural reforms post liberalisation and with their growing integration with rest of the world, academia has begun to investigate the macro economic variables critical to exchange rate determination and examine the importance of the monetary model in the case of emerging markets. Prominent in the academic literature, is the study of Liew, Baharumshah, and Puah [12] who successfully tested the flexible price monetary model for Thailand under the Johansen methodology. The results indicated that linear combination exists over a longer period between Baht/JPY exchange rate and the macroeconomic fundamentals of real income, inflation and interest rates.

In the Indian context however, very little work has been done in examining INR/USD exchange rate determination in monetary framework. Some of the literature includes Dua and Ranjan [1]; Shylajan, Sreejesh, \& Suresh [13]; Sharma and Setia [14] and Padake, Karamcheti and Geetha [15] that confirmed exchange rate determination using monetary approach is a long run phenomena. Dua and Ranjan [1] confirmed that monetary model variants along with market 
microstructure variables can be used to predict INR/USD exchange rate. Against this backdrop, the current study aims to estimate a model to determine INR exchange rate using FPM model and study the dynamic interaction among the variables.

\section{Specification of the Monetary Model}

The FPM model given by Frenkel [2], emerged as the most dominant model to explain exchange rate behavior in the early 1970s. The model assumes PPP holds and bonds (domestic and foreign) are perfect substitutes. This model explains the long run behavior of exchange rate when prices are flexible. The other variants of monetary model were developed by Dornbusch [16] and Frankel [17]. They were the sticky-price monetary model and real interest differential model respectively. Dornbusch [16] model pointed out that PPP holds only in the long run and any increase in the stock of money may not lead to increase in price in the short run as the prices are rigid in the short-run. Frankel [17] builds a medium term model by blending "flexible prices" and "rigid prices" and called it the real interest differential model. The present study aims to investigate the nature of INR/USD exchange rate for the longer horizon and hence FPM model is considered which is given as

$$
e_{t}=\left(m_{t}-m_{t}^{*}\right)+\alpha\left(i_{t}-i_{t}^{*}\right)-\beta\left(y_{t}-y_{t}^{*}\right)+\varepsilon_{t}
$$

where $e_{t}$ is the log exchange rate at time $t$. Variables $m_{t} i_{t}$ and $y_{\mathrm{t}}$ are the log of money supply, nominal interest rates and log of output in domestic economy respectively at time $t$. The foreign variables are represented by "*" and $\varepsilon_{\mathrm{t}}$ is the error term. The model suggests that the exchange rate is the relative value of difference in stock of money, interest rates and output in the domestic and the foreign economy. If domestic money supply is more than the foreign counterpart, price level increases leading to depreciation of currency. The differential output has negative impact on exchange rate and differential rate of interest has positive impact on exchange rate (as elasticities are identical for domestic and foreign money).

\section{Sample Period and Data Sources}

The study involves data collected from secondary sources. The time horizon for the study covers the period from April 1995 till December 2016. The data period commences from the year 1995, as prior to this period, post the liberalization reforms undertaken by India in 1991, India's foreign exchange market went through a transitional phase. The dual exchange rate system (LERMS) was introduced in the background of the balance of payment crisis of 1991. Subsequently, the dual exchange rate system was abolished and the exchange rate system transitioned from pegged to a floating regime. The years 1993 and 1994 witnessed the start of the market-based exchange rate regime and the adoption of current account convertibility respectively. It is due to these transformational 
changes that the sample period begins from the year 1995. The sample period ends in December of 2016 to conduct the variance decomposition analysis.

The stock of money for the US is measured by the broad money (M2) and short run interest rate is measured by 3-months Treasury Bill rate. In the case of India, money supply considered is M3 and the interest rate is 91-days Treasury Bill rate. In the current study, Index of Industrial Production (IIP) has been considered as proxy to the output, given the high correlation between the GDP and IIP. Similarly, for the U.S., Industrial Production Index is used as a proxy to GDP. The data source for INR/USD, M3, IIP and interests rates in India is the Reserve Bank of India database. The U.S. Federal Reserve System Database is the source for the US M2, 3-months Treasury Bill rate and Industrial Production Index (Table 1).

\section{Econometric Approach}

Similar to other studies focusing on exchange rate determination, the current study too adopts the Johansen and Juselius [18] cointegration methodology and examines the FPM Model in establishing the existence of long-run relationship among exchange rate (INR/\$) and other macroeconomic fundamentals such as relative money stock, relative output and rates of interest. The model is then estimated in a VAR framework and variance decomposition analysis has also been conducted.

\subsection{Unit Root Test}

The data under consideration is time series and may be non-stationary violating the assumption of stationarity in classical linear regression model. Hence the conventional practice in time series econometrics is to check if the series exhibits non-stationarity pattern by administering an array of unit root tests. The existence of non-stationarity can cause model misspecification and hence spurious regression. Non-stationarity is tested by performing conventional tests such as the Phillips and Perron (PP) test [19] and Augmented Dickey Fuller (ADF) test [20].

Table 1. Data sources.

\begin{tabular}{ccc}
\hline Variables & Description & Sources of Data \\
\hline$e$ & INR/USD & RBI Database \\
$m$ & M3 & RBI Database \\
$m^{*}$ & M2 & The U.S. Federal Reserve System Database \\
$y$ & Index of Industrial Production & RBI Database \\
$y^{*}$ & Industrial Production Index & The U.S. Federal Reserve System Database \\
$i$ & 91-days T-Bill rates & RBI Database \\
$I^{*}$ & 3-months Treasury Bill rates & The U.S. Federal Reserve System Database \\
\hline
\end{tabular}


The null hypothesis in ADF test [20] is formulated as the variable has a unit root. That is $\delta=0$ in the following equation, where $t$ denotes trend:

$$
\Delta Y_{t}=\beta_{1}+\beta_{2} t+\delta \sum_{i=1}^{m} \alpha_{i} \Delta Y_{t-i}+\varepsilon_{t}
$$

If the null hypothesis is rejected, it indicates the series to be stationary. Phillips and Perron test [19] is another popular non-stationarity test that considers weak dependence and heterogeneity in $\varepsilon$ t to cope with autocorrelation.

\subsection{Cointegration}

Cointegration procedure enables investigation of the long run validity of FPM model. The non-stationary series can be cointegrated if the linear combination of these series exhibit stationary pattern. Multivariate cointegration existence is tested using Johansen and Juselius [18] test. The cointegration test in a VAR framework is given below:

$$
\Delta y_{t}=\sum_{t=1}^{k} \Gamma_{t} \Delta y_{t-1}+\Phi y_{t-1}+\psi d+\varepsilon_{t}
$$

where $Y_{t}$ is a vector of non-stationary variables. The matrix $\Phi$ has reduced rank equal to $r$ and can be decomposed to $\Phi=\alpha \beta$. The error term is assumed to follow the normal distribution. The cointegrating rank $(r)$ can be tested with the maximum eigen value and the trace statistic.

\subsection{Granger Causality Test}

The direction of causality can be tested using Granger Causality test [21]. This test helps in finding causal relationships among the variables. The direction of causality using Granger causality test [21] for two independent variables $X$ and $Y$ can be expressed in VAR framework as:

$$
\begin{aligned}
& y_{t}=\alpha_{0}+\alpha_{1} y_{t-1}+\cdots+\alpha_{i} y_{t-i}+\beta_{1} x_{t-1}+\cdots+\beta_{i} x_{t-i}+\varepsilon \\
& x_{t}=\alpha_{0}+\alpha_{1} x_{t-1}+\cdots+\alpha_{i} x_{t-i}+\beta_{1} y_{t-1}+\cdots+\beta_{i} y_{t-i}+\varepsilon
\end{aligned}
$$

where, $X$ and $Y$ are variables, " $t$ " is the time and " $\mathcal{E}$ " is the error term. The Equation (8) examines causality from $X$ to $Y$, that is, the null hypothesis is defined as $X$ does not Granger-cause $Y$. If the null hypothesis is rejected, it indicates that $X$ is Granger caused by $Y$ and hence $X$ can be useful in predicting $Y$.

\subsection{Vector Auto Regression (VAR)}

If the direction of causality exists, the model can be estimated using VAR. After estimating the model in the sample period, variance decomposition is calculated to examine the dynamic behavior among the variables. The following section details the results of the above mentioned tests.

\section{Empirical Results}

This section reports the empirical results of the study starting from the descriptive statistics of the INR/USD over the sample period. The descriptive statistics is reported in Table 2 . The average exchange rate was 47.46 with a standard devia- 
tion of 8.69. The Indian rupee fluctuated between minimum of $31.39 / \$$ and $68.24 / \$$ during the sample period. The rupee appreciated in January 2008

(39.27/\$). The steep depreciation of Indian rupee was witnessed in May 2012 (54.33/\$) and in June 2013 (58.38/\$).

\subsection{Unit Root Test}

The results of non-stationarity test in levels and first difference are reported in Table 3. The PP and ADF test reveals that the null hypothesis that existence of unit root at levels could not be rejected. After transforming the variables in first difference, null hypothesis that unit root exist was rejected at $1 \%$ level. Hence we infer that the variables are I (1).

\subsection{Cointegration}

Since the variables are [I(1)], that is integrated of order one, Johansen and Juselius test [18] was conducted to identify the stationarity of the linear combination of exchange rate and FPM model variables. The results of cointegration test using trace statistic and maximum eigen value are reported in Table 4 and Table 5 .

The null hypothesis defined as the existence of zero cointegrating vectors that is $r=0$ against the alternative that at most one cointegrating vector exists. The results indicated that the null hypothesis was rejected implying the existence of one cointegrating vector $(r=1)$. Both the tests, namely, the maximum eigen value test and the trace test reveal the same results. The results indicate existence of cointegration of rank one. Hence we conclude that there is long run validity of FPM model variables and the exchange rate in case of INR/USD.

\subsection{Granger Causality Test}

The Granger causality test outcome is reported in Table 6 . The outcome shows that unidirectional causality exists from output differential, money stock

Table 2. Descriptive statistics.

\begin{tabular}{ccccc}
\hline Mean & Median & Minimum & Maximum & Standard Deviation \\
\hline 47.46 & 45.77 & 31.39 & 68.24 & 8.69 \\
\hline
\end{tabular}

Table 3. Test of Non-Stationarity.

\begin{tabular}{ccccc}
\hline & \multicolumn{2}{c}{ Augmented Dickey Fuller } & \multicolumn{2}{c}{ Philips and Perron } \\
\hline & At Level & First Difference & At Level & First Difference \\
\hline $\boldsymbol{e}$ & -2.1 & $-13.8^{*}$ & -2.2 & $-13.8^{\star}$ \\
$\left(\boldsymbol{m}-\boldsymbol{m}^{*}\right)$ & -1.5 & $-14.5^{*}$ & -1.2 & $-14.5^{*}$ \\
$\left(\boldsymbol{y}-\boldsymbol{y}^{*}\right)$ & -2.2 & $-10.8^{*}$ & -3.8 & $-39.8^{*}$ \\
$\left(i-\boldsymbol{i}^{*}\right)$ & -2.3 & $-12.4^{*}$ & -2.4 & $-14.1^{*}$ \\
\hline
\end{tabular}

Note: ${ }^{*}$ indicate significant at $1 \%$. 
Table 4. Trace: Cointegration rank test.

\begin{tabular}{ccccc}
\hline HO & & & Trace & 0.05 \\
\hline No. of cointegrating rank & Eigen-value & Statistic & Critical Value & Prob. $^{* *}$ \\
$r=0^{*}$ & 0.109132 & 65.73859 & 47.85613 & 0.0005 \\
$\boldsymbol{r} \leq 1$ & 0.10269 & 38.58219 & 29.79707 & 0.1038 \\
$\boldsymbol{r} \leq \mathbf{2}$ & 0.046889 & 13.11901 & 15.49471 & 0.1105 \\
$\boldsymbol{r} \leq \mathbf{3}$ & 0.007771 & 1.833327 & 3.841466 & 0.1757 \\
\hline
\end{tabular}

${ }^{* * *}$ at $1 \%,{ }^{* *}$ at $5 \%$ and ${ }^{*}$ at $10 \%$ level of significance.

Table 5. Maximum Eigen-value: Cointegration rank test.

\begin{tabular}{ccccc}
\hline Ho & & Max-Eigen & $\mathbf{0 . 0 5}$ \\
\hline No. of cointegrating rank & $\begin{array}{c}\text { Eigen- } \\
\text { value }\end{array}$ & Statistic & Critical Value & Prob. $^{* *}$ \\
$r \leq 1$ & 0.109132 & 27.1564 & 27.58434 & 0.0566 \\
$r \leq 2$ & 0.10269 & 25.46318 & 21.13162 & 0.115 \\
$r \leq 3$ & 0.046889 & 11.28568 & 14.2646 & 0.1405 \\
\hline
\end{tabular}

${ }^{* * *}$ at $1 \%,{ }^{* *}$ at $5 \%$ and ${ }^{*}$ at $10 \%$ level of significance.

Table 6. Granger Causality Test.

\begin{tabular}{ccccc}
\hline Ho & Lags & F-Statistic & P-value & Decision \\
\hline $\boldsymbol{e}_{\boldsymbol{t}}$ does not Granger caused by $\left(\boldsymbol{y}-\boldsymbol{y}^{*}\right)$ & 3 & 5.20846 & $0.0017^{\star * *}$ & Reject H0 \\
$\boldsymbol{e}_{\boldsymbol{t}}$ does not Granger caused by $\left(\boldsymbol{m}-\boldsymbol{m}^{*}\right)$ & 3 & 2.38083 & $0.0704^{*}$ & Reject H0 \\
$\boldsymbol{e}_{\boldsymbol{t}}$ does not Granger caused by $\left(\boldsymbol{i}-\boldsymbol{i}^{*}\right)$ & 3 & 3.07468 & $0.0285^{\star *}$ & Reject H0 \\
\hline
\end{tabular}

${ }^{* * *}$ at $1 \%,{ }^{* *}$ at $5 \%$ and ${ }^{*}$ at $10 \%$ level of significance.

differential and interest rate differential to exchange rate.

When causality in at least one direction exists, the model can be estimated at levels in a VAR framework. The lag length is determined by LR, FPE and AIC criteria. The model was estimated using VAR at levels with three lags and variance decomposition was also calculated (Appendix I). To ensure the robustness of the model and to make sure that the VAR residual are serially uncorrelated, the Lagrange Multiplier (LM) test was administered (Appendix II).

\subsection{Variance Decomposition}

In order to examine the fluctuation in INR/USD exchange rate caused by the shocks in FPM model variables, variance decomposition analysis was used. Variance decomposition analysis (VDA) is a useful technique in studying the dynamic interaction among the variables. It measures the forecast error variance (FEV) for one variable due to the change in other variables. In other words, VDA examines the proportionate changes in a variable caused by its own 
changes as well as changes to the other variables over time. VDA using the Choleski decomposition method was calculated for 24 months-ahead period and is reported in Table 7.

Table 7 reports the outcome of the first ordering of the variables $(e, m, i$, and y). The result shows that in the 1 period ahead forecast, most of the error variance are explained by its own shocks, that is, monetary variables do not contribute to the variation in exchange rate. At the end of the $6^{\text {th }}$ period FEV of exchange rate declines to 93.64 percent indicating that the exchange rate shock contributes maximum variation in the forecast error and monetary model variables namely stock of money, interest rate and output seem to have negligible impact. At the end of the $12^{\text {th }}$ period, exchange rate is affected by the stock of money, output and interest rates. During this period, around 85 percent of the exchange rate FEV is explained by its own shock and around 15 percent is explained by the monetary model variables. The FEV of exchange rate declines to 71 percent in the $18^{\text {th }}$ period while the FEV of the relative money stock is 5 percent, relative interest rates is 11.5 percent and relative output is 12 percent. At the end of the $24^{\text {th }}$ period, monetary model variables contributes around 38 percent variation in the forecast error. Among these variables, relative money supply account for 8 percent, relative interest rates contributes 15 percent and relative output causes 14 percent variation in the forecast error. The FEV of the exchange rate declines continuously in the long run. The result of the VDA, therefore, confirms that FPM model variables explain the variation in the INR/USD exchange rate during the longer period of time.

\section{Conclusions}

There exist numerous studies that have tested variants of monetary model in explaining exchange rate for developed and emerging economies, while the studies pertaining to India are few. The present paper aims to examine the FPM model in determining the INR/USD exchange rate. The study applied VAR framework for the monthly data spanning over April 1995 to December 2016. Cointegration using Johansen and Juselius was administered to test the common stochastic trend among the exchange rate and its determinants. The direction of causality was tested using Granger Causality test. The model was estimated in VAR with lag length of three and forecast error variance was calculated using variance decomposition technique.

Table 7. Variance Decomposition.

\begin{tabular}{cccccc}
\hline Period & S.E. & $e_{t}$ & $\left(m_{t}-m_{t}^{*}\right)$ & $\left(i_{t}-i_{t}^{*}\right)$ & $\left(y_{t}-y_{t}^{*}\right)$ \\
\hline 1 & 0.0196 & 100 & 0 & 0 & 0 \\
6 & 0.0489 & 93.643 & 0.516 & 3.211 & 2.631 \\
12 & 0.0652 & 84.991 & 1.682 & 6.24 & 7.088 \\
18 & 0.0766 & 71.408 & 5.096 & 11.449 & 12.048 \\
24 & 0.0846 & 62.353 & 8.169 & 15.318 & 14.161 \\
\hline
\end{tabular}


The finding of the cointegration suggested that the exchange rate determination under monetary model framework is a long-run phenomenon. The Johansen and Juselius test revealed the existence of cointegration among exchange rate and FPM model variables. The results are consistent with previous studies like Dua and Ranjan [1] and Padake, Karamcheti and Geetha [15]. If cointegration among the variables exists, causality exists in at least one direction. The existence of causality from monetary model variables to exchange rate was confirmed by the Granger causality test.

The results of variance decomposition showed that most of the exchange rate fluctuation is explained by its own shock in the short run and its determinants have negligible impact. Over the longer period of time, monetary model variables have a significant impact on exchange rate. The study adds new insights to the scant literature examining the effectiveness of the FPM model in explaining INR/USD exchange rate fluctuation.

The findings suggest that, the FPM model offers relevant explanation in determining INR/USD exchange rate during longer period. However, in the short run, FPM model cannot be considered as a useful framework in determining the exchange rate. Further research may consider the market microstructure variables like forward premia and order flow for the short run exchange rate determination. Alongside the linear models, non-linear models may also offer useful information in determining the INR/USD exchange rates.

\section{References}

[1] Dua, P. and Ranjan, R. (2011) Modelling and Forecasting the Indian Re/Us Dollar Exchange Rate. Working Paper No. 197. Centre for Development Economics.

[2] Frenkel, J.A. (1976) A Monetary Approach to the Exchange Rate: Doctrinal Aspects and Empirical Evidence. The Scandinavian Journal of Economics, 78, 200-224. https://doi.org/10.2307/3439924

[3] Bilson, J. (1978) The Monetary Approach to the Exchange Rate: Some Empirical Evidence. IMF Staff Papers, 25, 48-75. https://doi.org/10.2307/3866655

[4] Hodrick, R.J. (1978) An Empirical Analysis of the Monetary Approach to the Determination of the Exchange Rate. The Economics of Exchange Rates, 97-116.

[5] Putnam, B.H. and Woodbury, J.R. (1979) Exchange Rate Stability and Monetary Policy. Review of Financial Economics, 15, 1.

[6] Dornbusch, R. (1980) Exchange Rate Economics: Where Do We Stand? Brookings Papers on Economic Activity, 2, 143-150. https://doi.org/10.2307/2534287

[7] Alao, R.O., Oziegbe, T.R., Ibidapo, C.O.K. and Sharimakin, A. (2011) The Flex Price Monetary Model of the Dollar-Naira Exchange Rate Determination: A Cointegration Approach. British Journal of Arts and Social Sciences, 2.

[8] MacDonald, R. and Taylor, M.P. (1991) The Monetary Approach to the Exchange Rate: Long-Run Relationships and Coefficient Restrictions. Economics Letters, 37, 179-185. https://doi.org/10.1016/0165-1765(91)90128-8

[9] Dutt, S.D. and Ghosh, D. (2000) An Empirical Note on the Monetary Exchange Rate Model. Applied Economics Letters, 7, 669-671.

https://doi.org/10.1080/135048500415996 
[10] Miyakoshi, T. (2000) The Monetary Approach to the Exchange Rate: Empirical Observations from Korea. Applied Economics Letters, 7, 791-794. https://doi.org/10.1080/135048500444813

[11] Zhang, S.D. and Lowinger, T.C. (2005) Cointegration in a Monetary Model of Exchange Rate Determination. ASBBS E-Journal, 1, 1-18.

[12] Liew, V.K.S., Baharumshah, A.Z. and Puah, C.H. (2009) Monetary Model of Exchange Rate for Thailand: Long-Run Relationship and Monetary Restrictions. MPRA Paper No. 17715. http://mpra.ub.uni-muenchen.de/17715/

[13] Shylajan, C.S., Sreejesh, S. and Suresh, K.G. (2011) Rupee-Dollar Exchange Rate and Macroeconomic Fundamentals: An Empirical Analysis Using Flexible-Price Monetary Model. Journal of International Business and Economy, 12, 89-105.

[14] Sharma, C. and Setia, R. (2015) Macroeconomic Fundamentals and Dynamics of the Indian Rupee-Dollar Exchange Rate. Journal of Financial Economic Policy, 7, 301-326. https://doi.org/10.1108/JFEP-11-2014-0069

[15] Padake, V., Karamcheti, B. and Geetha, T. (2016) Does Existence of Long-Run Relationship Ensure Predictability of Exchange Rate? Empirical Analysis of Indian Rupee Vis-à-Vis US Dollar under Monetary Model Framework.

[16] Dornbusch, R. (1976) Expectations and Exchange Rate Dynamics. The Journal of Political Economy, 84, 1161-1176. https://doi.org/10.1086/260506

[17] Frankel, J. (1979) On the Mark: A Theory of Floating Exchange Rate Based on Real Interest Differential. American Economic Review, 69, 610-622.

[18] Johansen, S. and Juselius, K. (1990) Maximum Likelihood Estimation and Inference on Cointegration-With Applications to the Demand for Money. Oxford Bulletin of Economics and Statistics, 52, 169-209. https://doi.org/10.1111/j.1468-0084.1990.mp52002003.x

[19] Phillips, P.C.B. and Perron, P. (1988) Testing for a Unit Root in Time Series Regression. Biometrika, 75, 335-346. https://doi.org/10.1093/biomet/75.2.335

[20] Dickey, D.A. and Fuller, W.A. (1979) Distribution of the Estimators for Autoregressive Time Series with a Unit Root. Journal of the American Statistical Association, 74, 427-431.

[21] Granger, C.W.J. (1986) Developments in the Study of Cointegrated Economic Variables. Oxford Bulletin of Economics and Statistics, 48, 213-227. https://doi.org/10.1111/j.1468-0084.1986.mp48003002.x 


\section{Appendix I. Lag Length Criteria}

\begin{tabular}{|c|c|c|c|c|c|c|}
\hline \multicolumn{7}{|c|}{ VAR Lag Order Selection Criteria } \\
\hline Lag & $\log \mathrm{L}$ & LR & FPE & AIC & SC & HQ \\
\hline 0 & -98.39 & NA & $2.64 \mathrm{E}-05$ & 0.809 & 0.87 & 0.83 \\
\hline 1 & 1972.937 & 4060.791 & $2.32 \mathrm{E}-12$ & -15.44 & -15.16 & -15.33 \\
\hline 2 & 2020.007 & 90.79 & $1.81 \mathrm{E}-12$ & -15.68 & -15.18 & -15.48 \\
\hline 3 & 2038.249 & 34.61 & $1.78 \mathrm{E}-12$ & -15.702 & -14.98 & -15.41 \\
\hline 4 & 2047.57 & 17.38 & $1.88 \mathrm{E}-12$ & -15.65 & -14.69 & -15.27 \\
\hline 5 & 2056.943 & 17.19 & $1.98 \mathrm{E}-12$ & -15.6 & -14.42 & -15.12 \\
\hline 6 & 2065.503 & 15.42 & $2.11 \mathrm{E}-12$ & -15.54 & -14.14 & -14.97 \\
\hline 7 & 2080.194 & 26.02 & $2.13 \mathrm{E}-12$ & -15.53 & -13.91 & -14.88 \\
\hline 8 & 2084.816 & 8.04 & $2.34 \mathrm{E}-12$ & -15.44 & -13.59 & -14.7 \\
\hline
\end{tabular}

*indicates lag order selected by the criterion. LR: sequential modified LR test statistic (each test at 5\% level). FPE: Final prediction error. AIC: Akaike information criterion. SC: Schwarz information criterion. HQ: Hannan-Quinn information criterion.

\section{Appendix II. Residual Diagnostic Test}

Test for No serial Correlation

\begin{tabular}{ccc}
\hline & VAR Residual Serial Correlation LM Tests \\
\hline Lags & LM-Stat & Prob \\
\hline 1 & 30.73 & 0.0146 \\
2 & 33.17 & 0.007 \\
3 & 16.86 & 0.395 \\
4 & 19.75 & 0.2317 \\
5 & 9.55 & 0.89 \\
& Probs from chi-square with 16 df. & \\
\hline
\end{tabular}

